\title{
Vibration Control of Novel Passive Multi-joints Rotational Friction Dampers
}

\author{
Mualla, Imad H.; Koss, Holger
}

Published in:

Ce/papers

Link to article, DOI:

10.1002/cepa.190

Publication date:

2017

Document Version

Peer reviewed version

Link back to DTU Orbit

Citation (APA):

Mualla, I. H., \& Koss, H. (2017). Vibration Control of Novel Passive Multi-joints Rotational Friction Dampers. Ce/papers, 1, 1473-1482. https://doi.org/10.1002/cepa.190

\section{General rights}

Copyright and moral rights for the publications made accessible in the public portal are retained by the authors and/or other copyright owners and it is a condition of accessing publications that users recognise and abide by the legal requirements associated with these rights.

- Users may download and print one copy of any publication from the public portal for the purpose of private study or research.

- You may not further distribute the material or use it for any profit-making activity or commercial gain

- You may freely distribute the URL identifying the publication in the public portal

If you believe that this document breaches copyright please contact us providing details, and we will remove access to the work immediately and investigate your claim. 


\title{
Vibration Control of Novel Passive Multi-joints Rotational Friction Dampers
}

\author{
Imad Mualla*a, Holger Koss ${ }^{b}$ \\ ${ }^{\mathrm{a}}$ Damptech A/S, Brovej B.118, Lyngby, Denmark \\ ihm@damptech.com, \\ ${ }^{\mathrm{b}}$ Technical University of Denmark, Dept. Civil Engineering, Denmark \\ hk@byg.dtu.dk
}

\begin{abstract}
This work presents a novel passive friction damper for vibration control of structures.

The device is designed to dissipate input energy and protect buildings, especially large and tall buildings from structural and non-structural damage during moderate and severe vibration caused by earthquakes or strong winds. The damper is based on a rotational friction concept that was developed by Mualla, I.H. The devices have a stable energy dissipating behavior. They are flexible in the application, since they only need limited space. The devices can be installed easily. The damping capacity of the devices can be easily increased by adding additional friction layers. The friction damper device proves to be an efficient and economical device for a reduction of dynamic response of structures.

The damper has been tested intensively at the Technical University of Denmark and in Osaka, Japan confirming that the damper performance is:

- Independent of forcing frequency within applicable range

- Linearly dependent on displacement amplitudes

- Linearly dependent on normal forces

- Very stable over many cycles

Furthermore, a numerical model of the 4-joint damper has been developed based on an analytical derivation of the internal work in the damper. A comparison of results obtained from the experimental work and numerical model showed that the model well represented the behavioral characteristics of the damper, and that the dissipated energy was reliably predicted.

So far several models of the rotational friction dampers that are supplied by Damptech A/S have been installed in many projects in Japan, among them Japan tallest building and in other countries around the world. The paper provides a number of show cases demonstrating versatile application of rotational friction dampers (RFD).
\end{abstract}

Keywords: earthquake protection, friction damper, Buildings with dampers.

\section{INTRODUCTION}

Originating from the 70 -ies of the last century, the capacity design concept has now become a worldwide-accepted approach in earthquake-resistant design. It assumes that the structural system must be made as insensitive as possible to the strongly-variable and difficult-to-predict characteristics of seismic actions. This can be achieved only if the structural engineer introduces a hierarchy in the resistances of the structural members in a way which results in a well-predictable and ductile seismic performance. The capacity design concept is also referred to as "failure mode control" implying that the designer must provide favorable pattern of plastic (dissipative) zones not endangering the overall safety of the building/facility. It is also recognized that even structures made of very ductile materials, such as structural steel, have "brittle" components which must be protected from overstressing through providing extra-strength. In moment-resisting frames, this concept resulted in a design strategy called "strong-columns-weak-beams", implying that the ductile frame beams must be purposely made weaker than the frame columns in order to avoid formation of "weak" storey and/or total collapse initiated by premature column failure. 
Based on vast experience and lessons learnt from many major earthquakes it became clear that the conventional structures relying on their ductile response could really survive and save human lives but in general they failed to limit the extent of damage which resulted in heavy financial losses and business interruption. In this connection, the development of the structural fuse concept (SFC) i.e. the absorption of seismic energy by implementing sacrificial structural elements, can be viewed upon as a further step in the evolution of the capacity design philosophy.

Passive energy dissipation devices have been successfully used to effectively protect buildings and structures against earthquakes and storms. The primary reason for introducing energy dissipation devices into a building frame is to reduce the dynamic response and damage of the frame.

This paper presents the development, testing and application of a novel, worldwide patented friction damper system developed by Mualla,I.H. in order to control the vibration in structures and buildings due to earthquakes and/or strong winds. The capability of the dampers to dissipate energy has been extensively studied and tested in previous research programs both experimentally and numerically, as well as in several finalized projects. Friction damper devices have been used in many buildings and structures around the world because of their high-energy dissipation potential at a relatively low cost while being easy to maintain.

The dampers described in this paper are patented property of Damptech. The dampers are mainly used for vibration control of structures and base isolation of structures and are developed on a unique rotational friction concept. So far Damptech dampers have been installed in many projects around the World, including high-rise buildings in Japan.

\section{DESCRIPTION OF ROTATIONAL FRICTION DAMPER DEVICES}

The rotational friction damper (RFD) consists of several types of steel plates pre-stressed together by a steel bolt (Figure 1) to form a 2, 4, 6 or 8 Joint shape Figure 1A-B, Mualla et al. [2000,5]. Between the steel plates there are circular friction pad discs made of high-tech composite material. In order to have constant prestressing force several disc springs are used. Between these springs and the two external steel plates hardened washers are placed so that a uniformly distributed pressure can be achieved. The energy absorbing potential of the device can easily be increased by adding more layers of steel plates and friction pads.

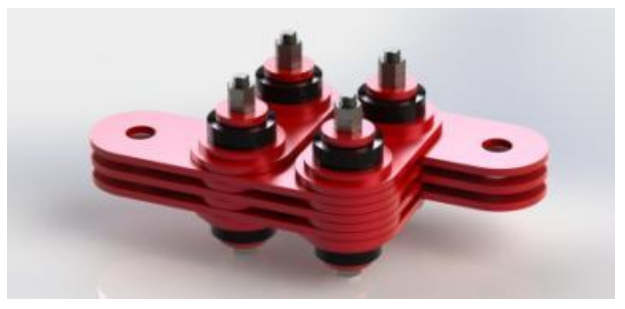

Figure 1A - Damptech four joint (4J) -damper

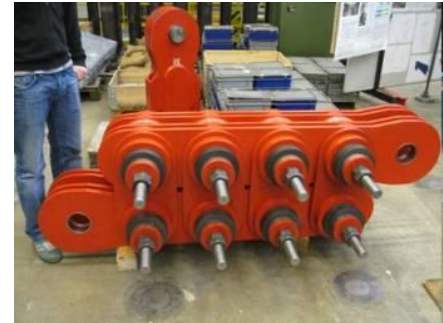

Figure 1B - Multi-joint large-capacity RFDs

A possible configuration of the device in a frame structure can be seen in Figure 2. The long plates are connected to the connection in the girder by a pin. In order to activate the energy absorbing mechanism of the device the other end of damper plates are connected to the steel bracing members. When the structure is vibrating the friction hinge is loaded in torsion. The friction at interface between the composite material and the steel plates resist the torsion with a sliding moment $M_{s}$, thus energy is dissipated when exceeding $M_{s}$ and rotation is activated when there is a rotation in the frictional hinge. The resistance due to the device hinders the lateral movement of the storeys. Consequently, if no further energy is induced, the vibration of the frame structure becomes smaller and smaller with each relative rotation between the steel plates. With the pre-stressing force of the bolt and the arrangement of the damper devices in the structure the degree of the resistance of the relative rotation at the device can be controlled. The simple mechanism allows an easy handling and installation. 

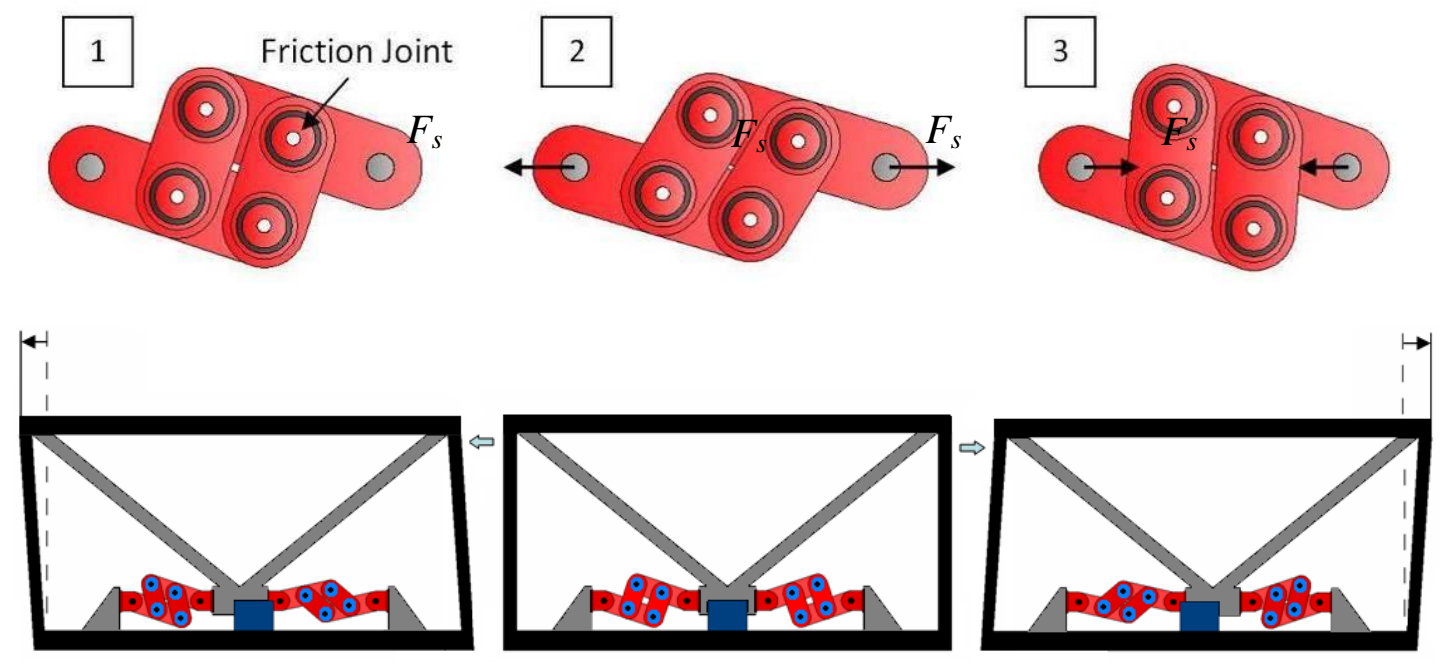

Figure 2 - Left: Frame structure moved to the left. Middle: Frame structure in initial position. Right: Frame structure moved to the right

\subsection{Features of RFDs}

The friction dampers are classified as displacement dependent devices and the features of the friction dampers are:

- For a given slip force $\left(F_{S}\right)$ and displacement $(\Delta)$ in a damper, the energy dissipation of a friction damper is greater than those of other damping devices.

- The dampers are not active during low velocity wind and service loads.

- The dampers do not contain any liquids so they cannot have any leakage and therefore they do not need to be inspected regularly and maintenance requirements are very low.

- The damper sliding moment $M_{s}$ is independent on velocity.

- The damper sliding moment $M_{s}$ is independent temperature.

\section{SHAKE-TABLE TESTS OF THREE-STOREY FRAME}

In 2001, an international team conducted intensive research program on a three-storey building equipped with RFDs at the advanced large-scale shake-table testing facility of the NCREE in Taiwan. The test building was a steel moment-resisting frame structure with $3.0 \mathrm{~m}$ storey height and $4.5 \mathrm{~m}$ bay width in the direction of shaking (Figure 3).
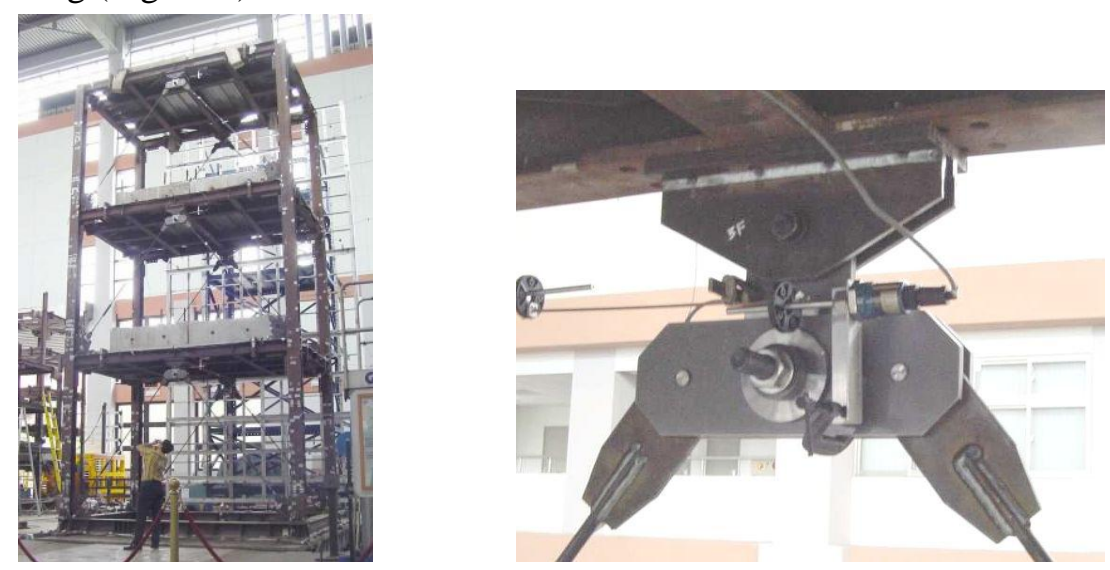

Figure 3 - Layout of full-scale testing at NCREE and closer view of one of the RFDs

The performance of the damped structure was evaluated for 14 cases of seismic input with peak ground acceleration (PGA) from $0.05 \mathrm{~g}$ to $0.30 \mathrm{~g}$. Several patterns of the damper slip resistances along the height of 
the building were used but each of them was kept for a couple of tests of different intensity. For example, the Kobe Takatori record was first applied with PGA $=0.1 \mathrm{~g}$ followed by consecutive shaking with PGA of $0.05 \mathrm{~g}, 0.15 \mathrm{~g}$ and $0.175 \mathrm{~g}$, respectively without readjusting the bolt clamping forces and device slip capacities. The other tests with stronger ground shaking $(\mathrm{PGA}=0.15 \mathrm{~g}-0.30 \mathrm{~g})$ demonstrated the remarkable efficiency of the damping system in reducing the lateral displacements and interstorey drifts of the test building by 70 to $80 \%$. More detailed information on the testing carried out in NCREE and its results can be found in [6].

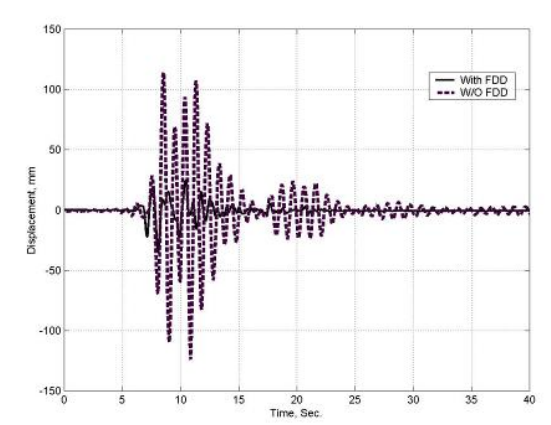

Figure 4- Roof displacement time-histories, with and without FDD, using Kobe Earthquake with 0.175g PGA

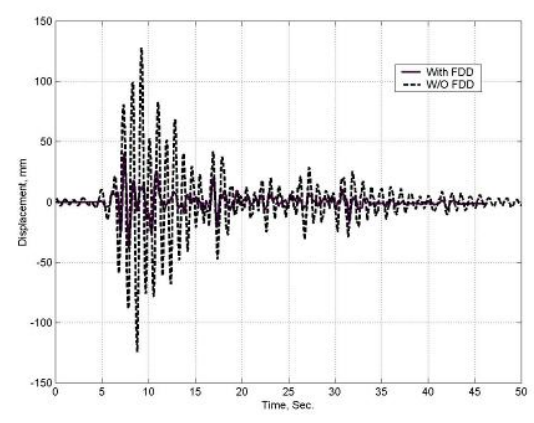

Figure 5- Roof displacement timehistories, with and without FDD, using El Centro Earthquake with 0.20g PGA

It is possible to estimate the equivalent viscous damping ratio of a single degree of freedom system with friction dampers subjected to sinusoidal loading, Mualla et al. [2001].

However, the equivalent viscous damping ratio depends on the amplitude of the sinusoidal load.

If the amplitude of the load is very low then the dampers will not activate and there will be no increase of equivalent viscous damping by using the dampers.

If the amplitude of the load is moderate or high (compared to the damper capacity) then the dampers are activated and dissipating the kinetic energy into thermal energy. In this case the dampers will increase the equivalent viscous damping ratio of the system.

The two phases of damper deformation are the sticking and sliding phases. The frictional moment $M_{f}$ limits the moment in the frictional hinge. This type of friction damper is defined by a slip load, $F_{s}$, an elastic stiffness, $K_{b d}$, and a ductility ratio, $\mu_{d}=D_{u} / D_{y d}$, where $D_{u}$ and $D_{y d}$ are the ultimate and yield displacements of the RFD, respectively. Energy dissipation $E D$ per cycle in the frictional hinge can be written approximately as

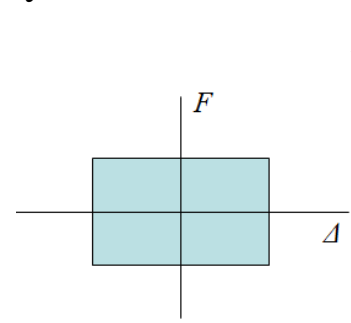

(a)

$$
E D=4 K_{b d} D_{y d}\left(D_{u}-D_{y d}\right)
$$

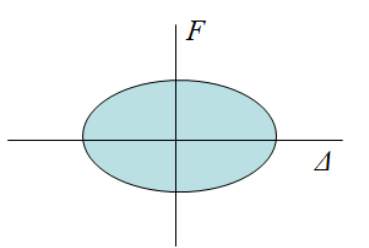

(b)

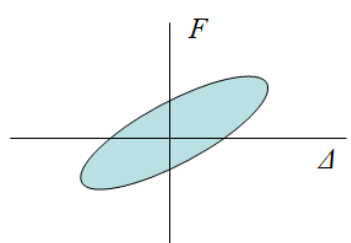

(c)

Figure 6 - Comparison of hysteresis loops of different dampers

(a) Friction damper; (b) Viscous damper; (c) Viscoelastic damper

Structure and RFD act in parallel and can be described as a dual system. For a system with a single degree of freedom and assuming that basic system remains elastic, the equivalent viscous damping ratio is obtained by

$$
\zeta_{e q}=\frac{2 F R(S R-F R)}{\pi\left(S R+F R^{2}\right)}, \frac{F R}{S R}<1
$$


Where, $F R$ is the ratio of the total structure force $F_{s}$ experienced by the structure, to the damper yield force $F_{h f}$. And $S R$ is the ratio of damper stiffness $K_{b d}$ to the total structure stiffness $K_{s}$ :

$$
F R=\frac{F_{h f}}{F_{s}} \quad \text { (3) } \quad S R=\frac{K_{b d}}{K_{s}}
$$

The total structure force $F_{s}$ experienced by the structure depends on the amplitude of the sinusoidal load and therefore $F R$ and also the equivalent viscous damping ratio $\zeta_{\text {eq }}$ depend on the amplitude of the sinusoidal load.

\section{SOME EXAMPLES WITH RFDS DAMPERS}

The first application of the friction damper devices in a real building was in two old temple buildings in Japan. The dampers are of the T-Damper model type.

Both temples were soft storey buildings because of the $1^{\text {st }}$ storey which had low stiffness compared to the rest of the building. By adding dampers and bracings at the $1^{\text {st }}$ storey the stiffness of the $1^{\text {st }}$ storey was increased while additional damping was added by the dampers.

The first temple to have Damptech dampers was the Yagurji Temple which can be seen in

Figure 7 below.

An example of the T-Dampers with bracings that are installed in the temple can be seen in

Figure 7.
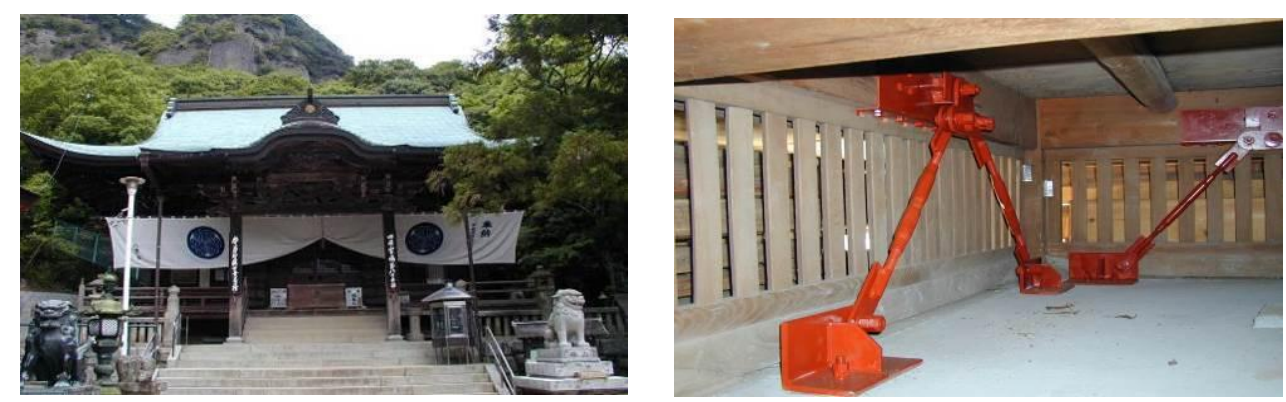

Figure 7 - Dampers with bracings installed in Yagutji Temple

A Scissor model dampers installed in an industrial building in Greece,. Since the completion of the project, several earthquakes have hit the region. The most significant were in June 2008 (M 6.5) and in August 07, 2011 (M 4.7) and August 20, 2011 (M4.9). The dampers have performed very well and no excessive displacements or effects of high forces have been observed in the structure.

Also in Greece RFDs with different capacities are used in 2 new office buildings as can be seen in Figure 8
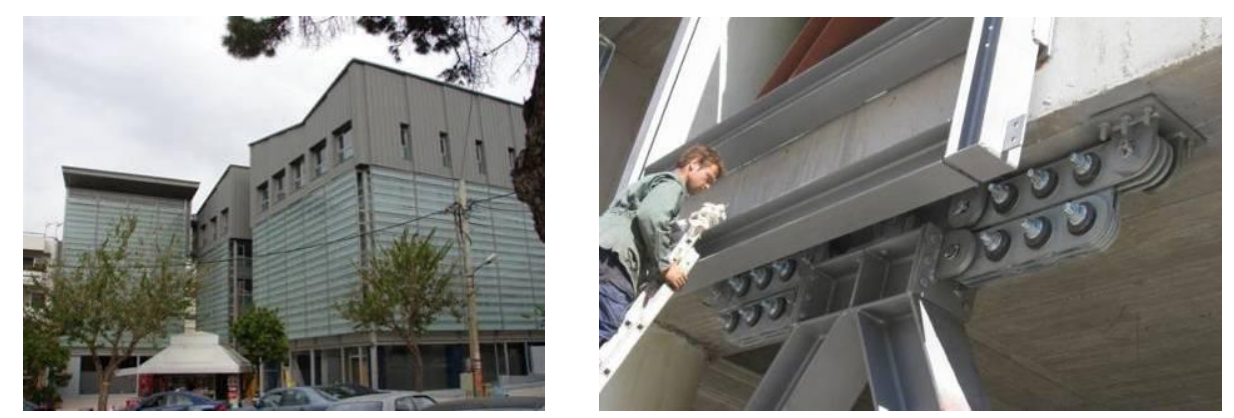

Figure 8 - Two New office building in Greece

\section{RFDS FOR BASE ISOLATION}

Damptech dampers have been used in several base isolated buildings in Japan.

(C) Ernst \& Sohn Verlag für Architektur und technische Wissenschaften GmbH \& Co. KG, Berlin · CE/papers (2017 
Base Isolation is a technique for protecting buildings and structures against earthquakes.

Basically the entire building stands on rubber bearings that are stiff in the vertical direction but soft in the horizontal plane (low shear stiffness).

In the event of an earthquake the ground starts to shake back and forth but because of the low shear stiffness of the rubber bearings the building remains almost stationary even though the relative displacement between building and the ground can be much larger than for a building without a base isolation system.

The dampers lower the response of the building further and ensure that the kinetic energy in the building is dissipated much quicker. The first project where Damptech dampers where used in base isolation was for a 5 storey laboratory building in Japan.

For this project base isolation friction dampers with high displacement capacity was used and tested at the Technical University of Denmark in a $250 \mathrm{kN}$ Instron dynamic testing machine.

For base Isolation the displacement requirements of the dampers can be very large and the dampers are designed for a maximum displacement of $+/-600 \mathrm{~mm}$.

The damper have a very stable performance and with no decrease in performance for over 100 cycles, Nielsen et al. [2004,2] , see Figure .

This good performance is owed to the use of a special friction pad material between the damper plates in the frictional hinge.

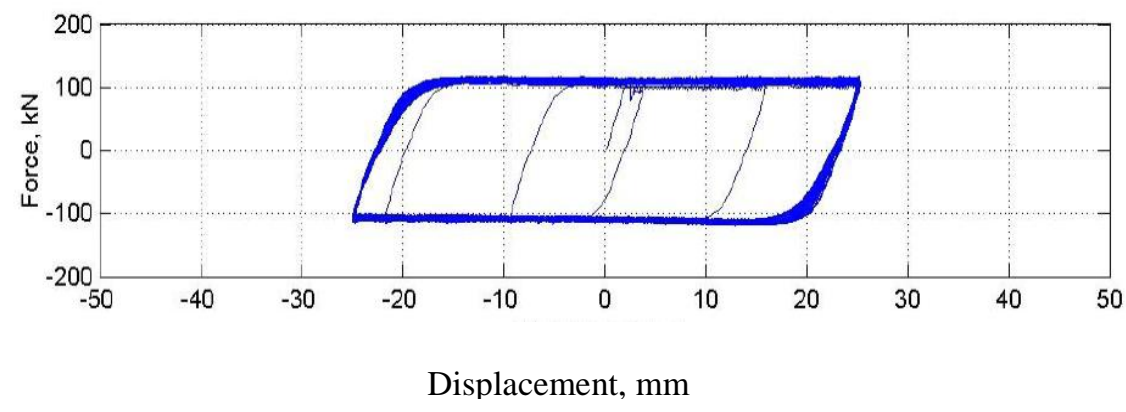

Figure 9 - 100 cycle test of base isolation damper

Since the 5 storey laboratory project several base isolated buildings of similar size have been equipped with Damptech dampers. One of them a 12 storey apartment building in Tokyo that was subjected to a strong earthquake in 2011. The building didn't have any kind of damages or problems because of the dampers.

\section{RFDS FOR BASE ISOLATION FOR HIGH-RISE BUILDINGS}

After the success of using the base isolation dampers for medium-rise buildings, it was decided to use the base isolation dampers in high-rise buildings also.

The first high-rise building to be equipped with Damptech dampers in base isolation configuration is a 144 tower in Osaka.

The tower is a residential tower with 44 floors and 2 pent house floors. (46 in total)

Other projects with Damptech dampers in base isolation configuration for high-rise buildings are three similar residential towers with 40 floors. Each tower is equipped with many base isolation dampers (Fig. 10,11). 


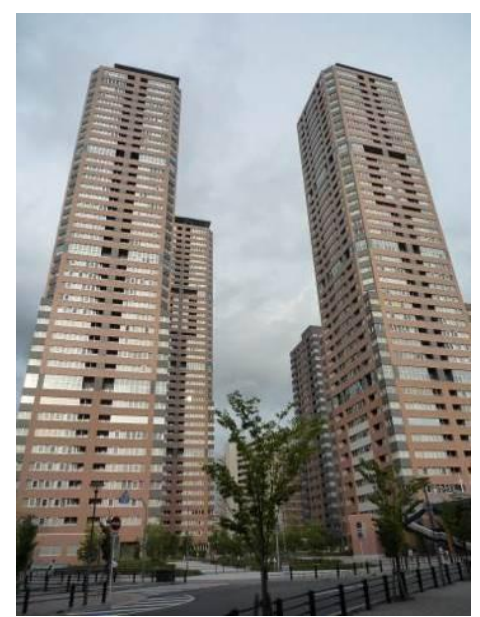

Figure 10 - Three residential towers with RFDs

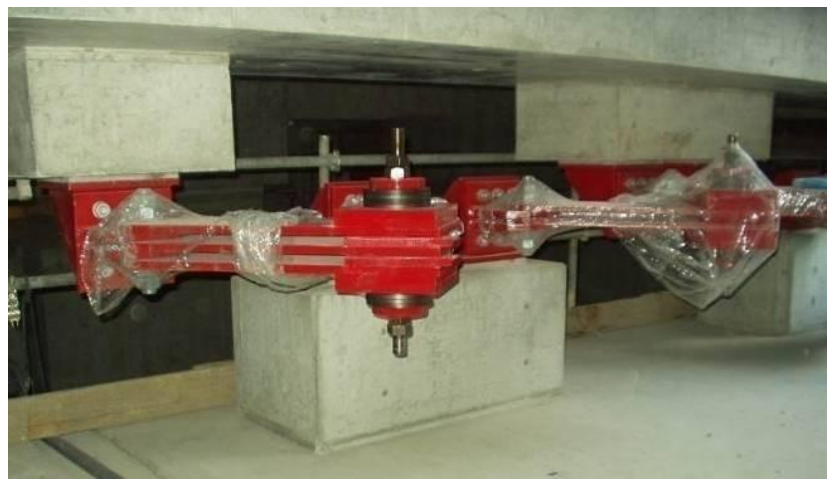

Figure 11 - Dampers installed in residential tower in Osaka, Japan

\section{RFDS FOR TALLEST BUILDING IN JAPAN}

Takenaka Corp. is currently building the tallest building in Japan, the "Abeno Harukas" building, with a height of $300 \mathrm{~m}$. The building will be used for department stores, hotel, museum, see Figure .

Because of its location in Osaka, an area with high seismic activity, it was decided to equip the building with Damptech friction dampers to reduce the demand on the primary structural elements in the event of an earthquake. All dampers have already been installed in the building.

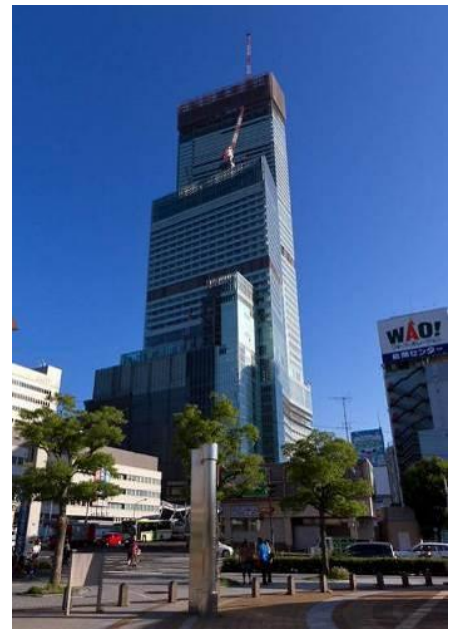

Figure 12 - Abeno Harukas October 2012 (under construction)

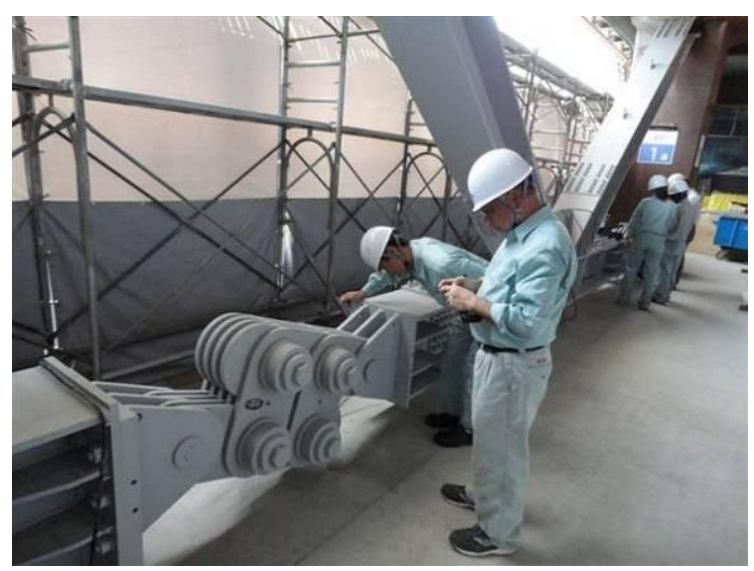

Figure 13 - $2250 \mathrm{kN}$ Dampers installed for base isolation in the Abeno Harukas building

The dampers used for the Abeno Harukas projects are as such unidirectional in the sense that a force $F_{s}$ is required to activate the dampers. The dampers in question has 4 friction joints and several layers of steel plates and friction pads to have a large damper capacity of $1500-2250 \mathrm{kN}$, Figure 13. 


\subsection{V-Bracing Configuration with RFDs}

The dampers have been installed in V-Bracings through the height of the $300 \mathrm{~m}$ building.

When the top of the frame structure is moved to the left the left damper is compressed while the right damper is in tension and both dampers dissipate energy. Similarly when the top of the frame structure is displaced to the right the right damper is compressed while the left damper is in tension and the dampers dissipate energy. Dissipating the kinetic energy from the earthquake into heat, effectively reduces the response of the structure to the earthquake.

\subsection{Experimental test program}

As a part of the Abeno Harukas Prjoect a large number of experiments for 1500-5000 kN dampers where been conducted at the Technical University of Denmark and testing facilities in Japan. The parameters examined are velocity dependence, displacement amplitude dependence, many loading cycles tests and etc..

\section{0-2250 kN Damper Tests}

The tests for the $1500 \mathrm{kN}$ damper was performed with a $3 \mathrm{MN}$ dynamic servo testing machine at testing facilities in Japan, Mualla et al. [2012]. Tests of a $5000 \mathrm{kN}$ dampers where tested at testing facilities at the Technical University of Denmark. The damper was tested in a Instron machine with $5000 \mathrm{kN}$ capacity in dynamic tests, Mualla et al. [2010]. The test setup is shown in Figure 14.
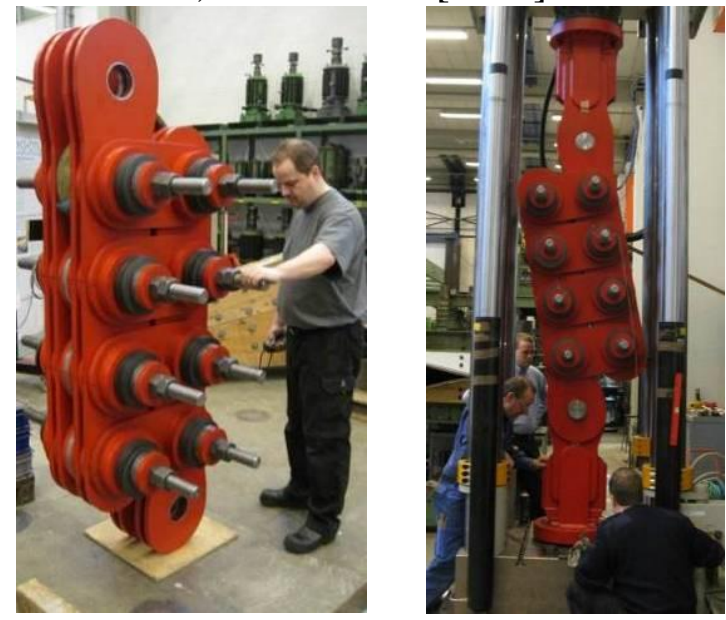

Figure 14 - 5000 kN Damper Tests at the Technical University of Denmark

Some of the building projects in Japan where Damptech dampers have been installed are shown in 15 below.

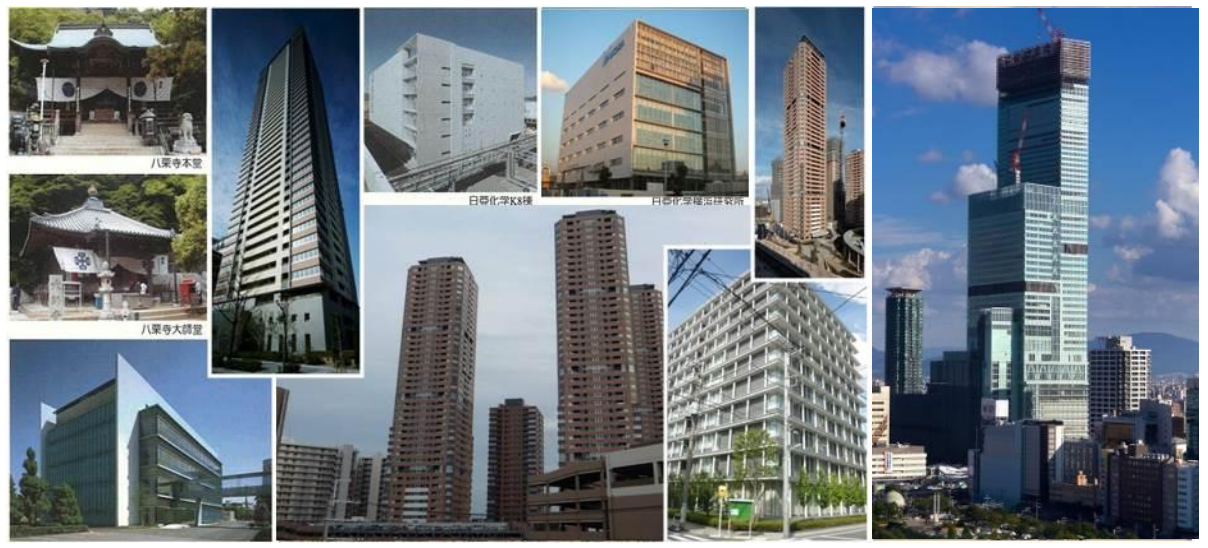

Figure 15 - Some Damptech projects in Japan (including tallest building in Japan) 
RFDs are used in other projects around the world. They are installed in large hospital project in Iran with 800 beds. Figure 16.
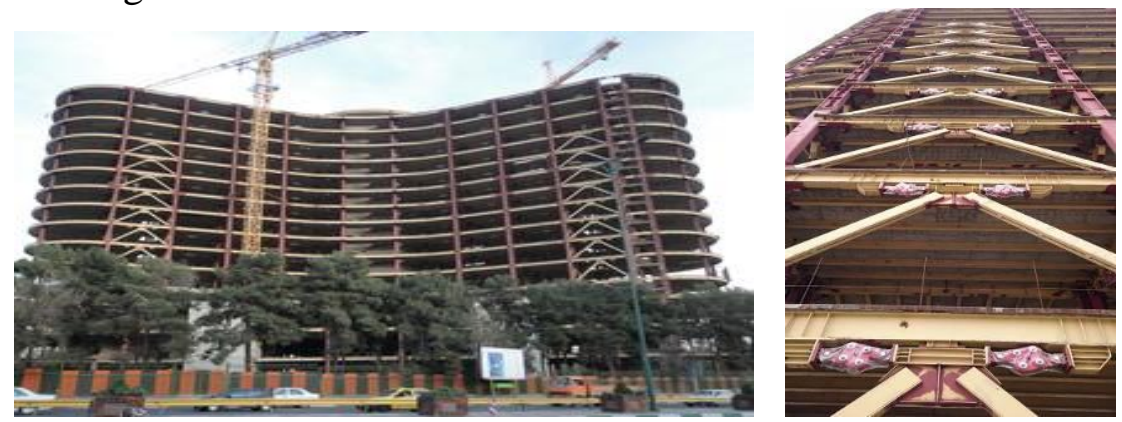

Figure 16 - Dampers installed in large hospital project.

\section{Cable vibration}

The Rotational Friction Dampers can be used in cable vibration and cable stayed bridges.

In Denmark 2 different models were used for cable stay bridge as shown in Fig 17 down below.
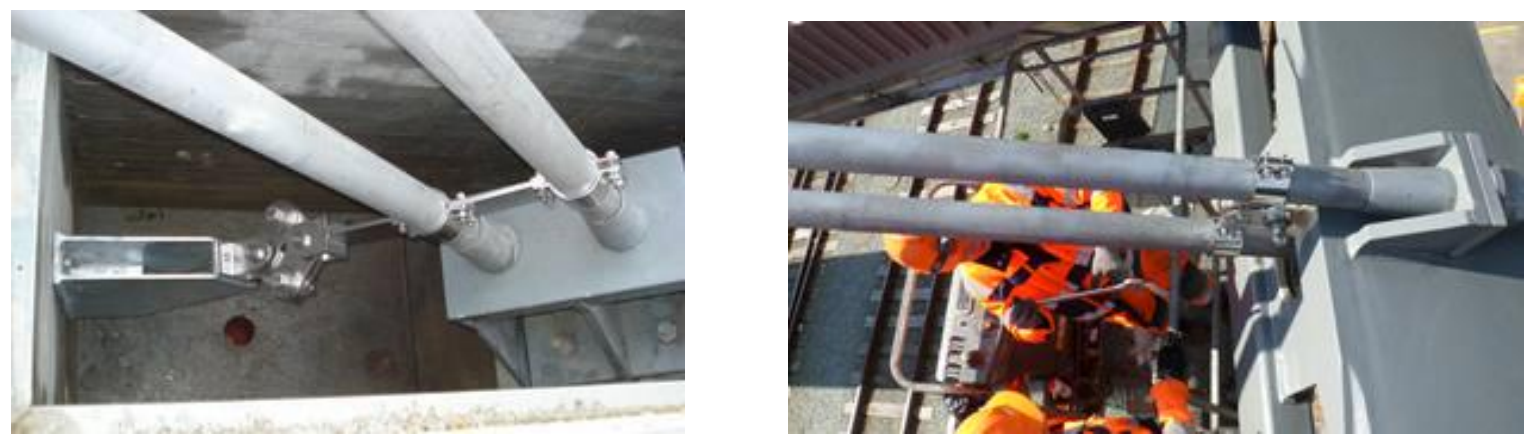

Figure 17 - Two models of Dampers installed in cable stay bridge in Denmark.

Another bridge in Qatar is under construction where the dampers will used to damp twin cables as shown in the Fig 18 below.
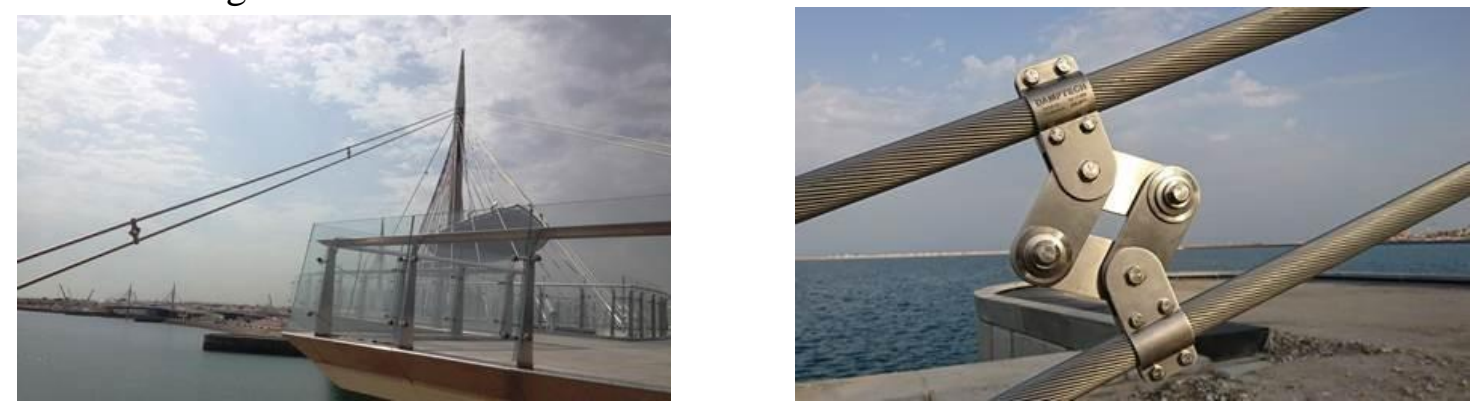

Figure 18 - Dampers will be installed in twin cables for cable stay bridge in Qatar..

\section{SEISMIC RETROFIT OF PRECAST RC STRUCTURES}

Passive energy dissipation systems and devices can be successfully used for seismic upgrade of singlestorey buildings with precast RC structure. Typical problems associated with this structural system are its relatively low lateral stiffness, low inherent damping, low structural redundancy and connections between primary structural members which are not suitable for seismic areas. The set of these drawbacks often results in severe damage in strong ground shaking. A study made in Turkey has revealed that the majority of the existing buildings of this type (industrial single-storey precast RC frame structures) are highly vulnerable to seismic actions and very few of them satisfy the provisions of current Turkish design code. An example of seismic retrofit of such building with V-shaped rotational friction dampers is shown in Figure 19. The major advantage of this approach is the fact that it can be implemented without any business interruption of the building. 


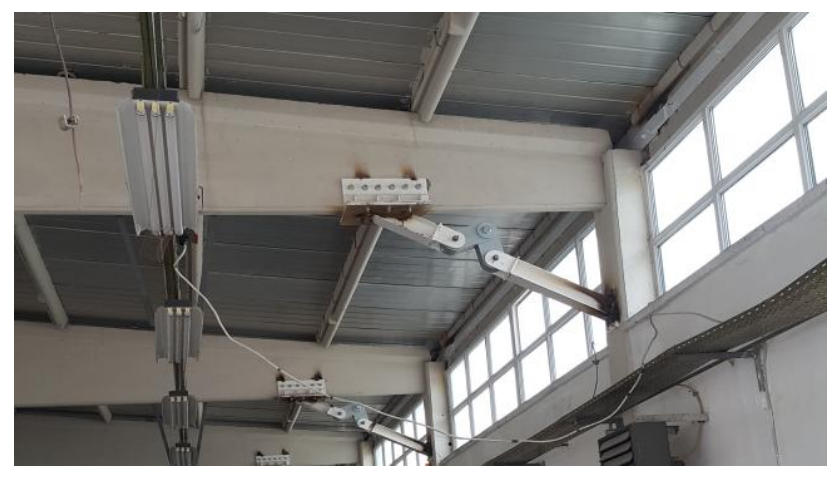

Figure 19 - V-shaped rotational friction dampers on precast RC structure

\section{CONCLUSION}

A number of damping systems developed by Damptech and based on a unique rotational friction concept, having worldwide patents have been presented and discussed. These systems are very effective in damping vibration in buildings and structures.

The dampers have been successfully used in many projects around the world including the tallest building in Japan.

The devices can be used to efficiently protect building against earthquakes, storms and can also be used for reducing machine vibration.

The devices are flexible and available in many different models that each have their own advantage for certain applications.

\section{REFERENCES}

[1] Mualla, I.H., Belev, B. [2001], Performance of steel frames with a new friction damper device under earthquake excitation. Journal of Engineering Structures, Elsevier.

[2] Liao, W.I., Mualla, I.H., Loh, C.H. [2004,1], Shaking-table test of a friction-damped frame structure., Struct. Design Tall Spec. Build. 13, 45-54, Published online 9 June 2004 in Wiley Interscience (www.interscience.wiley.com). DOI:10.1002/tal.232

[3] Nielsen LO, Mualla IH, Iwai Y. [2004,2], Seismic isolation with a new friction-viscoelastic damping system, 13th World Conference on Earthquake Engineering, Vancouver, Canada.

[4] Nielsen L.O., Mualla I.H, Iwai Y., Nagase T. [2008], Seismic isolation systems based on frictional visco-elastic dampers., The $14^{\text {th }}$ World Conference on Earthquake Engineering October 12-17, Beijing, China.

[5] Mualla IH, Nielsen LO, Sugisawa M, Suzuki Y. [2012], Large capacity dampers for buildings and structures, 15h World Conference on Earthquake Engineering, Lisbon, Portugal.

[6] Mualla, I.H., Nielsen, L.O., Belev, B., Liao, W.I., Loh, C.H., Agrawal, A. [2002,1], Performance of friction-damped frame structure: shaking table testing and numerical simulations. 7th U.S. National Conference on Earthquake Engineering, Boston, USA

[7] Mualla, I.H., Nielsen, L.O., Belev, B., Liao, W.I., Loh, C.H., Agrawal, A. [2002,2], Numerical predictions of shaking table tests on a full scale friction-damped structure. 12th European Conference on Earthquake Engineering.

[8] Mualla, I.H., Nielsen, L.O., Jakupsson E.D. [2010], Structural behaviour of $5000 \mathrm{kN}$ damper. 14th European Conference on Earthquake Engineering. 